\title{
Reproductive biology of the male Cape porcupine, Hystrix africaeaustralis
}

\author{
R. J. van Aarde and J. D. Skinner \\ Mammal Research Institute, University of Pretoria, Pretoria 0002, South Africa
}

\begin{abstract}
Summary. The reproductive tract of the male Cape porcupine is morphologically and histologically similar to that of New World hystricomorph rodents. Males are reproductively active throughout the year and attained sexual maturity (complete spermatogenesis) at an age of 8-18 months. Testes weight, epididymides weight and seminiferous tubule diameter attained asymptotic values at the age of 23-30 months. A tendency towards seasonality in the activity of accessory glands, preceded and accompanied by an increase in circulating plasma testosterone values, may be considered as a factor enforcing seasonal breeding in females. Testosterone concentrations in pubertal males were significantly higher than those recorded in sexually mature males.
\end{abstract}

\section{Introduction}

The Cape porcupine (Hystrix africaeaustralis) is a large nocturnal hystricomorph rodent occurring throughout southern Africa where it is sometimes used as a source of food and often regarded as a nuisance by crop-producing farmers. Male hystricomorph rodents have not been studied as extensively as females and published information on Hystrix species is limited to descriptions of the anatomical (Tohmè \& Tohmè, 1981) and histological (Weir, 1967) characteristics of the reproductive tract.

Hystricomorph rodents do not have a true scrotum and the penis is directed posteriorly. The surface of the glans penis of most species is covered with spines or spicules (Pocock, 1922, in Weir, 1974) and the presence of a sacculus urethralis is considered characteristic of the suborder (Weir, 1974). No hystricomorph males have been reported to be seasonal breeders, nor do their gonads regress periodically. On the other hand, while captive Cape porcupine females cycle throughout the year, free-ranging females in southern Africa only produce litters in summer (van Aarde, 1985a).

The present study deals with aspects of the reproductive biology of the male Cape porcupine and is based on material obtained from free-ranging males culled in an area subject to seasonal climatic changes. Incidental information obtained from captive males is included.

\section{Materials and Methods}

Animals. Material was obtained during a culling programme in the Tussen-die-Riviere Game Farm $\left(30^{\circ} 25^{\prime} \mathrm{S}, 26^{\circ} 12^{\prime} \mathrm{E}\right)$ in the Karoo abutting the Orange River. The climate of the area is defined as arid, cold and dry with a mean annual temperature less than $18^{\circ} \mathrm{C}$. The mean minimum daily temperature for the coldest month (July) is $0.1^{\circ} \mathrm{C}$ and the mean maximum daily temperature for the hottest month (January) is $31.2^{\circ} \mathrm{C}$ (Werger, 1973). Winters are dry and the summer rainy season extends from November to April with an average annual rainfall of $440 \mathrm{~mm}$ (Werger, 1980).

Fifty-six males were shot at night from February 1977 to January 1978 and 64 from July 1981 to June 1982. Immediately after death, blood was collected in heparinized glass tubes through cardiac puncture and duplicate plasma fractions were stored at $-20^{\circ} \mathrm{C}$. Carcasses were weighed and 
processed within $4 \mathrm{~h}$ after being collected and testes, epididymides, seminal vesicles and prostate glands were weighed before fixation in Bouin's fluid. After fixation for $24 \mathrm{~h}$ these were stored in $70 \%$ ethanol. Testicular samples from all males and epididymides and samples from prostate glands of some males were later dehydrated, embedded in paraffin wax, sectioned at $5 \mu \mathrm{m}$ and stained with Delafield's haematoxylin and eosin. Sections of the testes were examined for the stage of spermatogenesis and seminiferous tubule diameter for each male was calculated as the mean of 25 tubules measured in cross-section using a calibrated micrometer eyepiece and a $\times 10$ objective. All means are given with one standard deviation ( \pm s.d.) of the mean.

Examination of the maxillar toothrows provided an opportunity to assign each specimen to one of 9 dental age classes. Chronological age were assigned to 6 of these on the basis of the age-specific sequence of tooth eruption and replacement recorded in known aged porcupines (van Aarde, 1985b).

Testosterone assay. Concentrations of peripheral plasma testosterone were estimated by radioimmunoassay of duplicate plasma aliquants $(0.05$ or $0.1 \mathrm{ml})$ following extraction with $4 \mathrm{ml}$ diethyl ether (Merck, Darmstadt, F.R.G.). Dried extracts were dissolved in $0.1 \mathrm{ml}$ phosphate buffer (pH $7.0)$ containing $1 \%$ methanol $(\mathrm{v} / \mathrm{v})$. Standards ranging from 3.9 to $1000 \mathrm{pg}$ testosterone $\left(\Delta^{4}\right.$ androsten-17/-ol-3-one; Sigma Chemical Co., Dorset, U.K.) per $0.1 \mathrm{ml}$ phosphate buffer and buffer blanks were prepared in duplicate and included in each assay. Antiserum in phosphate buffer $(0 \cdot 1 \mathrm{ml})$ at a dilution of 1:800 was added to standards, reagent blanks and plasma extracts. This was followed by the addition of $\left[1,2,6,7-{ }^{3} \mathrm{H}\right]$ testosterone (sp. act. $349 \mathrm{mCi} / \mathrm{mg}$; Radiochemical Centre, Amersham, Bucks, U.K.) in $0.1 \mathrm{ml}$ assay buffer ( $\sim 10000$ c.p.m.). The contents of each tube were mixed thoroughly and incubated for $60 \mathrm{~min}$ at $37^{\circ} \mathrm{C}$ and then at $4^{\circ} \mathrm{C}$ for $30 \mathrm{~min}$. Separation of antibody-bound and free testosterone was carried out at $4^{\circ} \mathrm{C}$ by adding $0.5 \mathrm{ml}$ dextran-coated charcoal consisting of a suspension of charcoal (Aktivole; Merck, Darmstadt, F.R.G.) in assay buffer $(0.25 \mathrm{~g} / 100 \mathrm{ml})$ containing $0.025 \mathrm{~g}$ Dextran T-40 (Pharmacia, Uppsala, Sweden) to the contents of each tube.

These solutions were mixed gently for $30 \mathrm{sec}$, incubated at $4^{\circ} \mathrm{C}$ for $10 \mathrm{~min}$ and centrifuged at the same temperature at $1500 \mathrm{~g}$ for $10 \mathrm{~min}$. The supernatants were decanted into scintillation vials and scintillation fluid ( $4.0 \mathrm{ml}$ ) (Ready-Solve CP; Beckman Instruments (Pty) Ltd, Johannesburg, South Africa) was added to each vial. The contents of the vials were mixed properly and radioactivity was measured at least $4 \mathrm{~h}$ later for $2 \mathrm{~min}$, using a Beckman LS 5800 Scintillation Counter.

A standard curve of percentage radioactivity bound was plotted against the logarithm of the concentrations of testosterone over the range 3.9-1000 pg/tube and testosterone contents of each tube were determined by interpolation on the standard curve. The recovery of known amounts of $\left[1,2,6,7-{ }^{3} \mathrm{H}\right]$ testosterone $(\sim 1000$ c.p.m. $)$ in phosphate buffer to which aliquants $(0.05$ or $0.1 \mathrm{ml})$ of pooled plasma from adult males were added, served to determine procedural losses incurred during extraction. Extraction efficiency and the original volume of plasma extracted were taken into account when calculating the concentrations of testosterone in plasma samples.

Validations. The antiserum was raised in rabbits against testosterone-3-carboxymethyl-oxime conjugated to bovine serum albumin as described by Millar \& Kewley (1976). Cross-reaction with all major naturally occurring steroids was $<0 \cdot 1 \%$ except for dihydrotestosterone for which it was $8 \cdot 1 \%$.

The sensitivity of the assays, defined as twice the standard deviation of the blank values (Jeffcoate, 1981), ranged from 237.6 to $370.6 \mathrm{pg} / \mathrm{ml}$ (mean $290 \cdot 7 \pm 70 \cdot 4$ s.d.; $n=3$ ). Six buffer blanks included in three assays contained $205.7 \pm 49.7 \mathrm{pg}$ testosterone equiv. $/ \mathrm{ml}$. Recovery estimates varied from $89 \cdot 1$ to $92 \cdot 8 \%$ (mean $91 \cdot 2 \pm 1 \cdot 9 ; n=3$ ) and were not affected by volume over the range $0 \cdot 05-0 \cdot 1 \mathrm{ml}$ plasma. Intra-assay coefficient of variation calculated according to the method of Jeffcoate (1981) was $5 \cdot 3 \%$. Interassay coefficient of variation for a plasma sample containing $730 \pm 47 \mathrm{pg}$ testosterone $/ \mathrm{ml}$ was $6.4 \%$ and for a sample containing $6283 \pm 757 \mathrm{pg} / \mathrm{ml}$, 
$13 \cdot 6 \%$. Addition of $1000 \mathrm{pg}$ testosterone $/ \mathrm{ml}$ to a plasma pool (stripped of steroids) included in all assays resulted in a recovery of $102 \pm 1 \%$.

\section{Results}

\section{Anatomy of the reproductive tract}

The S-shaped penis of the Cape porcupine is posteriorly directed when not erected and the subcutaneous testes are not suspended in a scrotum. The surface of the glans penis of the adult male is covered with inconspicuous spicules and the well-developed sacculus urethralis is only pronounced when the penis is fully erect (Fig. 1). The accessory glands (vesicular gland, prostate and Cowper's glands) are well developed in the adult with the prostate being divisible into a left and right lobe. The fluid of the diverticulated seminal vesicles forms a gel when mixed with that of the prostate and presumably forms the copulatory plug after copulation.

\section{Age-related characteristics}

Age-related mean combined testes, epididymides, prostate and vesicular gland weights, mean seminiferous tubule diameter and mean plasma levels of testosterone are summarized in Table 1. Maximum mean testes, epididymides, prostate and vesicular gland weights were recorded for males in age classes VII and VIII (older than 30 months). Mean weight of the paired testes $(6 \cdot 6 \pm 2 \cdot 1 \mathrm{~g}$; $\mathrm{N}=17$; Table 1) recorded for age class VI (23-30 months) did not differ significantly $(t=0 \cdot 51)$ from that recorded for age classes VII $(6 \cdot 8 \pm 2 \cdot 1 \mathrm{~g} ; \mathrm{N}=22)$ and VIII $(7 \cdot 6 \pm 1 \cdot 6 \mathrm{~g} ; \mathrm{N}=21$; $t=1 \cdot 7$ ), suggesting that asymptotic testicular weight was attained at an age of 23-30 months.

The relationship between paired testes weight and body weight is presented in Fig. 2. Separate lines were fitted for sexually immature (age classes II-III) and mature males (age classes IV-IX). The increase in testicular weight with body weight was significant $(r=0.73 ; P<0.001 ; \mathrm{N}=50)$ only for the immature animals.

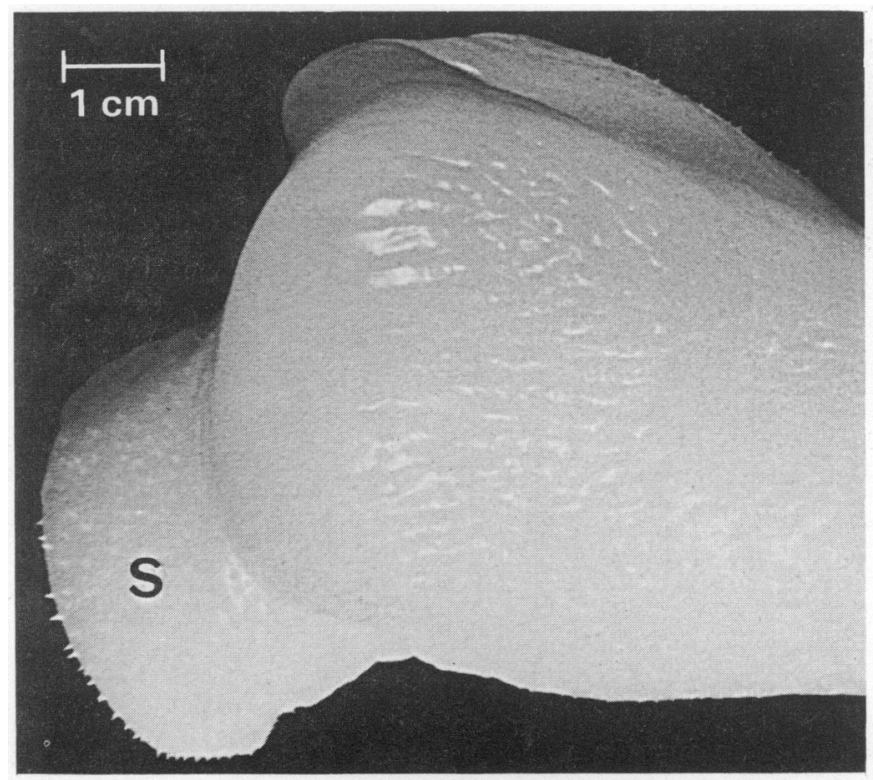

Fig 1. Glans of a fully erected penis of an adult porcupine illustrating the sacculus urethralis (s) and spicules on the glans. 


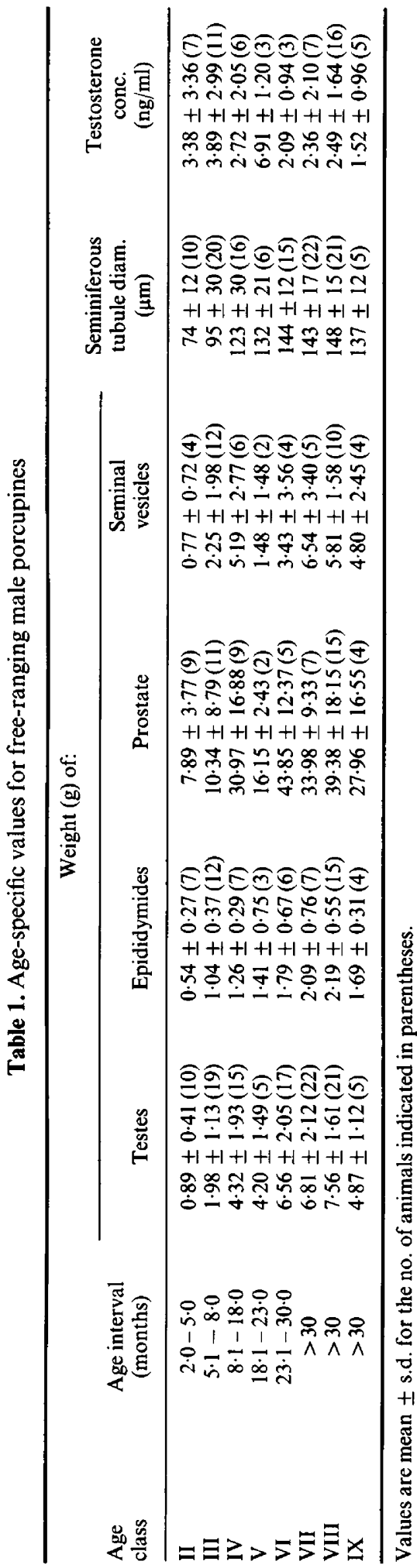




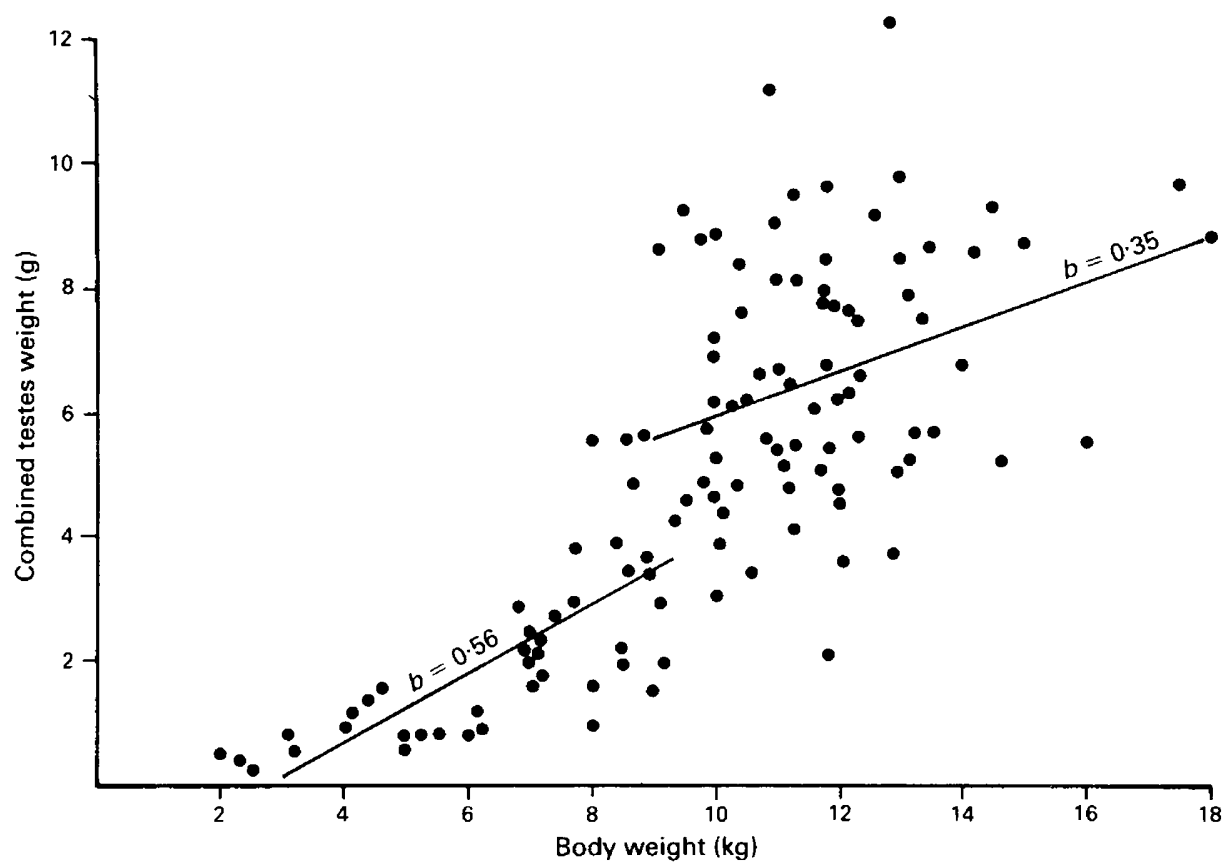

Fig. 2. The relationship between paired testes weight and body weight for porcupines $(\mathrm{N}=124)$ culled on the Tussen-die-Riviere Game Farm between February 1977 and July 1982. Separate lines were fitted through least square regression analyses for males in age classes II-III $(y=0.56 x-1.5)$ and IV-IX $(y=2.52+0.35 x)$, the latter representing sexually matured males.

Seminiferous tubule diameter peaked in age class VIII $(0 \cdot 148 \pm 0.015 \mathrm{~mm} ; \mathrm{N}=21)$ but this value did not differ significantly from the mean recorded for age classes VI $(t=0.82)$ and VII $(t=1.54)$. This suggests that asymptotic seminiferous tubule diameter $(0.144 \pm 0.012 \mathrm{~mm}$; $\mathbf{N}=15$ ) may be attained at an age of 23-30 months. Mean seminiferous tubule diameter increased linearly $(y=0.85 x+0.008)$ and significantly $(r=0.73 ; P<0.001)$ with an increase in paired testes weight.

None of the males in age class III (5-8 months) exhibited full spermatogenic activity, while $73.3 \%$ of the 15 males in age class IV ( $8-18$ months) were undergoing spermatogenesis with complete maturation of germ cells to spermatozoa. Gonocytic elements were present in the seminiferous tubules of all males in age classes V-IX (older than 18 months).

Plasma testosterone concentrations for males in age class IV (8-18 months) varied from 0.43 to $4.48 \mathrm{ng} / \mathrm{ml}$ (mean $2.72 \pm 2.05 ; \mathrm{N}=6$ ) and did not differ significantly $(t=0.84$ ) from those recorded in younger males. Mean seminiferous tubule diameter for males in this age group $(0.123 \pm 0.03 \mathrm{~mm} ; \mathrm{N}=16)$ was, however, significantly $(t=3.45 ; P<0.001)$ greater than that found in younger males, but significantly smaller $(t=-3.00 ; P<0.001)$ than values recorded for males 18-30 months old (age classes $\mathrm{V}$ and VII). The mean testosterone value recorded for males $18-23$ months old $(6 \cdot 91 \pm 1 \cdot 2 \mathrm{ng} / \mathrm{ml})$ was significantly higher than that recorded for older males (Table $1 ; t=5 \cdot 06 ; P<0 \cdot 001$ ).

A captive born male fertilized a parous female when 10 months old and mounting accompanied by thrusting was recorded in males at a minimum age of 8 months $(N=3)$.

\section{Seasonality}

Spermatogenesis, as suggested by the presence of spermatogonia, spermatocytes, spermatids and spermatozoa in the seminiferous tubules of adult males ( $>18$ months of age) occurred 
throughout the year. Combined testes weight and epididymides weight for adult males did not change seasonally (Figs 3a \& b), while mean vesicular and prostate gland weights increased from May to July, with the mean values recorded for the period January-May being lower than those recorded from July to December (Figs $3 \mathrm{~d} \&$ e). These differences were significant $(t=-4.96$ and -5.50 for prostate and vesicular gland weights respectively; $P<0.001$ ). However, the increase in mean seminiferous tubule diameter from July to September, followed by a decrease from September to December (Fig. 3f) was not statistically significant ( $t=1.43$ and -0.13 respectively).

Mean plasma testosterone concentrations increased from a nadir of $0.98 \pm 0.44 \mathrm{ng} / \mathrm{ml}$ in January to $3 \cdot 31 \pm 2 \cdot 11 \mathrm{ng} / \mathrm{ml}$ in March, with mean values remaining above $3.0 \mathrm{mg} / \mathrm{ml}$ up to July, decreasing thereafter until December. However, these changes were not statistically significant $(t=-2.04$ and 0.99 respectively).
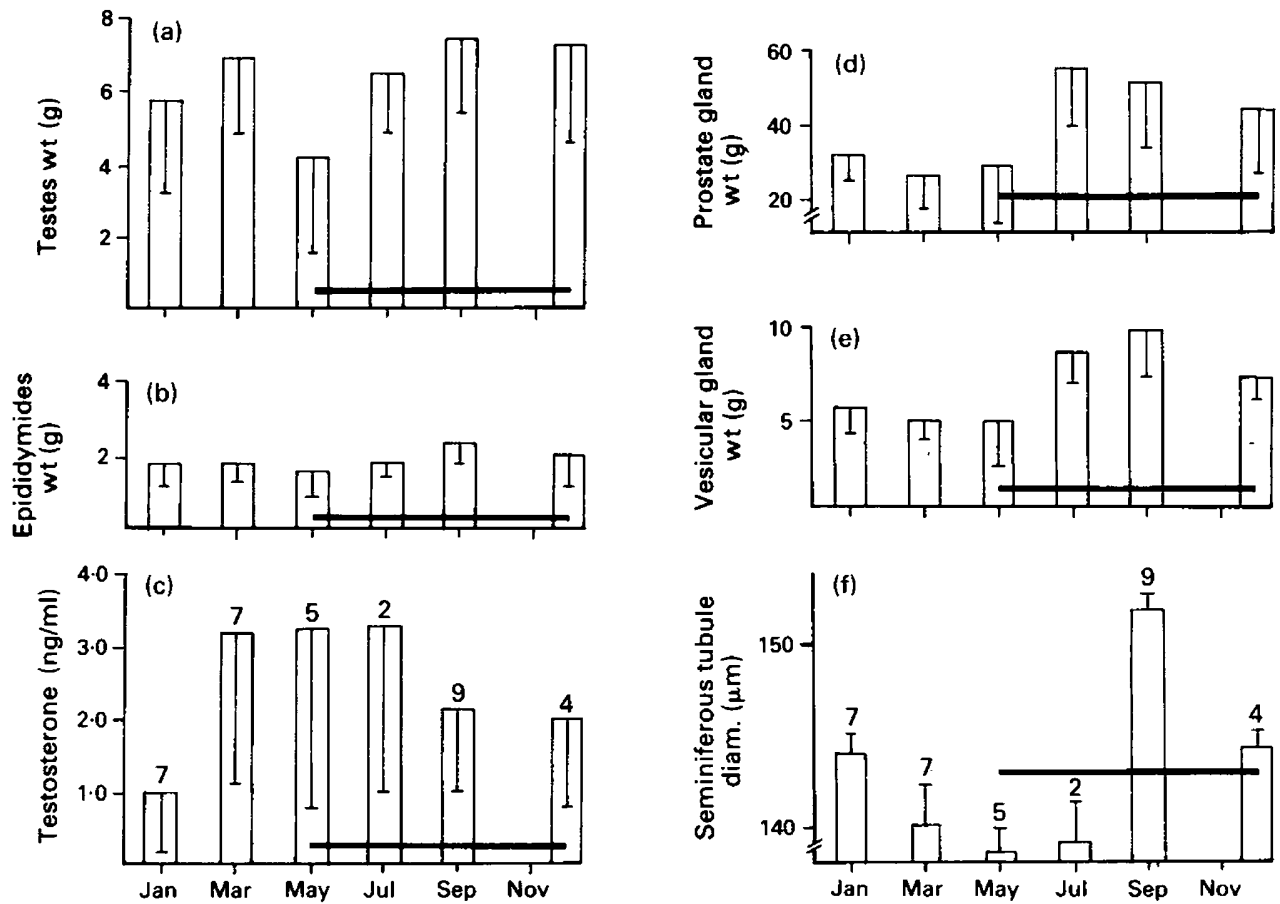

Fig. 3. Seasonal changes in mean testes weight, epididymides weight, prostate weight, vesicular gland weight and mean testosterone levels in adult porcupines culled on the Tussen-die-Riviere Game Farm between September 1981 and July 1982. Sample sizes are given above the means and vertical lines present one standard deviation. Horizontal bars denote the period of successful conceptions.

\section{Discussion}

The appearance of the external genitalia of the Cape porcupine is similar to that described for African porcupine species by Mohr (1965), for the crested porcupine by Weir (1967) and for the Indian porcupine by Tohmè \& Tohmè (1981). The microscopic appearance of the testes, epididymides and prostate was also similar to that of the crested porcupine (see Weir, 1967).

Circulating concentrations of testosterone in porcupines varied from $400 \mathrm{pg} / \mathrm{ml}$ to $10.9 \mathrm{ng} / \mathrm{ml}$ and the highest value was recorded for a male 5-8 months of age. The values recorded for adult males varied from $400 \mathrm{pg} / \mathrm{ml}$ to $5 \cdot 8 \mathrm{ng} / \mathrm{ml}$ and were similar to those recorded for aduit guinea-pigs, 
but lower than those recorded for the rabbit, bull, monkey and man (Rigaudiere, Pelardy, Robert \& Delost, 1976, for references). Rigaudiere et al. (1976) ascribed the relatively low levels of testosterone in the plasma of guinea-pigs to the absence of testosterone-binding globulin, resulting in a high metabolic clearance rate of testosterone. The high efficiency of extraction of testosterone from porcupine plasma without the prior denaturation of proteins might be considered indicative of the absence of testosterone-binding proteins and thus explain the relatively low circulating values recorded.

Testosterone concentrations in pubertal porcupine males are significantly higher than those recorded in sexually mature males. This is in agreement with observations in guinea-pigs, mice, rats (Rigaudiere et al., 1976) and rabbits (Berger et al., 1976). The relatively high testosterone values in pubertal males may be due partly to modified testicular sensitivity to gonadotrophins (Odell, Swerdloff, Bain, Wollesen \& Grover, 1974). For rams Lee, Bremner, Cumming, de Kretser \& Findlay (1981) indicated that changes in sensitivity to gonadotrophins may play a role in the initiation of the pubertal process. However, pituitary-testicular relationships in porcupines have not yet been investigated.

Minimum age at fecundity in captivity (10 months) was of the same order as that recorded (8-18 months) when full spermatogenic activity began in free-ranging porcupines, but the pairbond social system in porcupines (van Aarde, 1984; Morris \& van Aarde, 1985) may prevent young sexually mature males from breeding before becoming socially established. Males aged 8-10 months were observed to mount females but this may be an artefact of captivity as these males were housed with their natal family groups for extended periods.

Cape porcupines in captivity breed throughout the year while free-ranging animals breed seasonally, with the period of successful conceptions on the Tussen-die-Riviere Game Farm lasting 8 months, from May to December (van Aarde, 1984; Skinner, van Aarde \& van Jaarsveld, 1984). The full spermatogenic cycle observed in seminiferous tubules of all adult males suggests that males, in general, have the ability to fertilize ova throughout the year. The increase circulating concentrations of testosterone (although not significant) before the breeding season and the statistically significant heavier weights of prostate and vesicular glands (Text-figs $3 \mathrm{~d} \& \mathrm{e}$ ), probably in response to the increased testosterone secretion, may be indicative of some degree of reproductive seasonality in males. This is however not supported by the trends in testes weight, epididymides weight and seminiferous tubule diameters (Figs 3a, b \& f). The seasonal trend in testosterone secretion and the weights of the accessory glands producing the copulatory plug cannot yet be explained in terms of environmental or physiological variables. Captive males provided with a constant supply of food and exposed to relatively natural environmental conditions (photoperiod, temperature and ventilation) are fertile throughout the year and so seasonal breeding in porcupines may, with the information available, best be explained in terms of factors affecting the female (see van Aarde, 1985a).

The Mammal Research Institute provided logistical and financial support. We thank the staff of the Conservation Management Subdivision of the Orange Free State Provincial Administration for their kind cooperation in this project; and Amanda Nel for the figures. R. J. van A. was the recipient of the Charles Astley Maberly Memorial Scholarship of the Transvaal Branch of the Wildlife Society of Southern Africa.

\section{References}

Berger, M., Chazaud, J., Jean-Faucher, Ch., de Turckheim, M., Veyssiere, G. \& Jean, Cl. (1976) Developmental patterns of plasma and testicular testosterone in rabbits from birth to 90 days of age. Biol. Reprod. 15, 561-564.
Jeffcoate, S.L. (1981) Efficiency and effectiveness in the endocrine laboratory. Academic Press, London.

Lee, V.W.K., Bremner, W.J., Cumming, I.A., de Kretser, D.M. \& Findlay, J.K. (1981) Effects of LH-RH infusion castration and cryptorchidism on gonado- 
trophin and testosterone secretion in developing rams. J. Reprod. Fert., Suppl. 30, 111-118.

Millar, R.P. \& Kewley, C. (1976) Production of a specific antiserum for testosterone. S. Afr. Med. J. 50, 1021-1022.

Mohr, E. (1965) Altweltliche stachelschweine. A. Zeimsen, Wittenberg, Lutherstadt.

Morris, D. \& van Aarde, R.J. (1985) Sexual behavior of the female porcupine Hystrix africaeaustralis. Horm. Behav., (in press).

Odell, W.D., Swerdloff, R.S., Bain, J., Wollesen, F. \& Grover, P.K. (1974) The effect of sexual maturation on testicular response to $\mathrm{LH}$ stimulation of testosterone secretion in the intact rat. Endocrinology 95, $1380-1384$.

Rigaudiere, N., Pelardy, G., Robert, A. \& Delost, P. (1976) Changes in the concentrations of testosterone and androstendione in the plasma and testis of the guinea-pig from birth to death. $J$. Reprod. Fert. 48, 291-300.

Skinner, J.D., van Aarde, R.J. \& van Jaarsveld, A.S. (1984) Adaptations in three species of large mammals (Antidorcas marsupialis, Hystrix africaeaustralis, Hyaena brunnea) to arid environments. S. Afr. J. Zool. 19, 82-86.
Tohmè, G. \& Tohmè, H. (1981) Quelques donnees anatomiques sur le porc-epic Hystrix indica indica Kerr, 1792 (Rodentia). Mammalia 45, 363-371.

van Aarde, R.J. (1984) Reproduction in the porcupine Hystrix africaeaustralis Peters. D.Sc. Thesis, University of Pretoria.

van Aarde, R.J. (1985a) Reproduction in captive female Cape porcupines (Hystrix africaeaustralis). $J$. Reprod. Fert. 75, 577-582.

van Aarde, R.J. (1985b) Age determination of Cape porcupines Hystrix africaeaustralis. S. Afr. J. Zool. 20, 232-236.

Weir, B.J. (1967) Aspects of reproduction in some hystricomorph rodents. Ph.D. thesis, University of Cambridge.

Weir, B.J. (1974) Reproductive characteristics of hystricomorph rodents. Symp. zool. Soc. Lond. 34, 265-301.

Werger, M.J.A. (1973) An account of the plant communities of Tussen die Riviere Game Farm, OFS. Bothalia 11, 165-176.

Werger, M.J.A. (1980) Phytosociological study of the upper Orange River valley. Mem. Bot. Surv. S. Afr. 46.

Received 11 April 1985 